\title{
Christhardt Henschel
}

https://orcid.org/0000-0001-5403-2911

German Historical Institute in Warsaw

\section{THE POLISH ARMY GHETTO: THE INTERNSHIP OF JEWISH SOLDIERS IN JABŁONNA IN 1920}

\begin{abstract}
At the height of the Polish-Soviet War in August 1920, the Polish army interned thousands of its Jewish soldiers at Jabłonna near Warsaw. Although the internees were released after several weeks, the events gave rise to numerous domestic and foreign policy debates and shaped Polish-Jewish relations in the years to come. 'Jabłonna' stands pars pro toto for the problems of the Polish state and Polish society in dealing with a heterogeneous population at the beginning of the interwar period. In recent decades, the events surrounding the internment have been taken up and contextualised sporadically by historians and publicists, but usually without them having made recourse to the available archival sources.
\end{abstract}

Keywords: Polish-Soviet War (1919-21), Battle of Warsaw (1920), Polish-Jewish relations, Polish Armed Forces (1918-39), anti-Semitism, anti-Jewish violence

On 1 August 1920, Deputy Minister Kazimierz Sosnkowski instructed the 1st Division of the Ministry of Military Affairs [Ministerstwo Spraw Wojskowych, MSWojsk.] to limit the number of Jewish soldiers in military units stationed around the Polish capital. Five days later, the secret order No. 13679/MOB signed by Colonel Rudolf Prich arrived at the Headquarters of Staff Command [Dowódca Oddziału Generalnego, DOG] Warsaw:

In connection with the increasing frequency of cases, which testifies to the harmful activities of the Jewish element, MSWojsk. so orders the following ... DOG Warsaw will remove all Jewish privates from all its subordinate formations, stationed in Warsaw, Modlin, Jabłonna, and Zegrze, leaving only 
$5 \%$ of this element in the said formations. DOG Warsaw will designate an assembly point for these withdrawn Jews... It should also be noted that all Jewish privates should be removed from the offices and orderly rooms of respective staff units and departments. ${ }^{1}$

Over the following weeks, several thousand Jewish soldiers were interned in the garrison at Jabłonna near Warsaw, in what is today Legionowo. Historians often mention these events in the decisive phase of the Polish-Bolshevik war; but to date, there has been no detailed study of the exact circumstances and events. The number of internees and the living conditions have been variously presented in the literature, and some of the information provided is either contradictory or unfounded. The purpose of this paper is to redress this research gap. Apart from the circumstances that led to the decision to remove Jews from the army, the subject of what follows will be the course of events and the nature of the internment. The public debate around 'Jabłonna' will also be discussed, as well as its long-term impact on the Polish-Jewish culture of remembrance.

II

\section{VIOLENCE AND HYSTERIA. POLISH ARMED FORCES ON THE MARCH TO JABŁONNA}

Within the scope of this article, it is impossible to comprehensively present the debate on the national structure and the function of the Polish army as a nation-building institution in both the First World War and in the early post-war years. An important aspect of this discourse was the question of the extent to which Jews could have been part of the national armed forces. Many people argued that Jews, who were not considered part of the Polish national community, should be removed from the army and not admitted to front-line service. In the military, Jews were often subject to harassment and discrimination. ${ }^{2}$

${ }^{1}$ Centralne Archiwum Wojskowe Wojskowego Biura Historycznego (hereinafter: CAW WBH), Oddział I Sztabu Ministerstwa Spraw Wojskowych (hereinafter: Oddz. I Szt. MSWojsk.), sygn. I.300.7.108, Liczb. 3679/MOB, L.dz. 7011/WM 20.

${ }^{2}$ Out of 106 parliamentary appeals in 1920 concerning abuses in the army, 50 came from Jewish members of parliament; Archiwum Akt Nowych (hereinafter: AAN), Biuro Sejmu (hereinafter: BS), sygn. 34, 11-14. Cf. also AAN, Akta Instytucji Wojskowych 1916-1939 (hereinafter: IW), sygn. 296/I-16, 8-9; and a two-volume 
At the same time, after 1918, there was an unprecedented wave of antiSemitic violence by soldiers against the Jewish civilian population. Both exclusion and violence accompanied the genesis of the Polish army from its inception and created the immediate context for Jabłonna. ${ }^{3}$

In the summer of 1920, anti-Jewish sentiment in the press and society had whipped up a collective sense of fear and hysteria. In addition, there were reports of Jewish communist organisations forging documents that would allow Jews to avoid military service. The state reacted by dissolving the Bund and the trade unions and by interning their activists. ${ }^{4}$ The military hierarchy, however, was aware of the diverse attitudes of the Jewish population. Situational reports clearly distinguished 'categories' of Jews based on their social standing and political leanings. ${ }^{5}$ Furthermore, military observers saw the reasons for the sympathy of some Jews for the Bolsheviks as being reflected in "the behaviour of our soldiers during the forced retreat". ${ }^{6}$ The majority of the Jewish population in the front-line zones, as confirmed by reports, adopted a wait-and-see attitude; or, not infrequently, supported the Polish cause. ${ }^{7}$

However, at the rear of the front, rumours of Jewish disloyalty began to disseminate widely, leading to an increasing number of attacks

document published by the Narodowy Klub Żydowskich Posłów Sejmowych przy Tymczasowej Żydowskiej Radzie Narodowej [National Club of Jewish Sejm Members at the Provisional Jewish National Council] (hereinafter: NKŻPS), Inwazja bolszewicka a Żydzi. Zbiór dokumentów (Warszawa, 1921).

3 Piotr J. Wróbel, 'The Revival of Poland and Paramilitary Violence, 1918-1920', in Rüdiger Bergien and Ralf Pröve (eds), Spießer, Patrioten, Revolutionäre. Militärische Mobilisierung und gesellschaftliche Ordnung in der Neuzeit (Göttingen, 2010), 281-303.

4 Gertrud Pickhan, "Gegen den Strom". Der Allgemeine Jüdische Arbeiterbund "Bund" in Polen 1918-1939 (Stuttgart, 2001), 81; Norman Davies, White Eagle, Red Star: The Polish-Soviet War 1919-1920 and the Miracle on the Vistula (Granville, OH, 19721), I used a Polish translation by Andrzej Pawelec: Orzet Biaty, czerwona gwiazda. Wojna polsko-bolszewicka 1919-1920 (Kraków, 2012), 199; Janusz Szczepański, Społeczeństwo Polski $w$ walce $z$ najazdem bolszewickim 1920 roku (Warszawa-Pułtusk, 2000), 248; Frank Golczewski, Polnisch-jüdische Beziehungen 1881-1922. Eine Studie zur Geschichte des Antisemitismus in Osteuropa (Wiesbaden, 1981), 241.

${ }^{5}$ CAW WBH, Samodzielny Referat Informacyjny (hereinafter: SRI), sygn. I.371.2/ A.8, 7. This and similar reports have been made available to diplomatic missions; AAN, Embassy of the Republic of Poland in Berlin, sygn. 389, 16-19; ibid., Embassy of the Republic of Poland in Washington, sygn. 2608, 90-7.

${ }^{6}$ CAW WBH, SRI, sygn. I.371.2/A.8, 7.

${ }^{7}$ Ibid., 8-12. 
by soldiers against Jewish civilians. ${ }^{8}$ The first wave of violence took place during the Polish retreat in July $1920 .^{9}$ In the next month, the Polish forces launched a counterattack and pushed the Red Army eastwards. Another wave of anti-Jewish violence began, which lasted until the ceasefire on 8 October. ${ }^{10}$ Even MSWojsk. had to admit that the behaviour of the army 'left much to be desired', and thus the pro-Polish sympathies among the local Christian and Jewish population in the captured territories had been recklessly wasted. ${ }^{11}$ It was only at the end of July 1920 that the army leadership opposed the illegal requisitions. ${ }^{12}$ Shortly before the Jabłonna decision, Sosnkowski, at the request of Prime Minister Grabski, ordered on 30 July that all violence against Jews should cease and would be met with severe penalties. ${ }^{13}$ Nevertheless, the Chief of General Staff, Rozwadowski, had to reiterate the order in September, calling on all commanders to curb their violence against Jews. ${ }^{14}$

There were more and more calls in the press for the army to engage in 'Jew-ousting.' ${ }^{15}$ Piłsudski was presented as a puppet of international

${ }^{8}$ E.g. CAW WBH, Gab. MSWojsk., sygn. I.300.1.48-59, passim; CAW WBH, Oddział II Sztabu Generalnego (hereinafter: Oddz. II SG), sygn. I.202.4.331.

${ }^{9}$ I.a. Biblioteka Sejmowa, RPII/0/1938, Interpelacja posłów Grünbauma, Farbsteina i tow., 4 March 1921. Cf. CAW WBH, Gab. MSWojsk., sygn. I.300.1.56, Liczb. 904/22.

${ }^{10}$ Central Zionist Archives (hereinafter: CZA), Grünbaum Papers, A127/366 and $\mathrm{A} 127 / 367$.

${ }^{11}$ AAN, Akta Prezydium Rady Ministrów (hereinafter: PRM), Rkt. 49, 4, 288-9; AAN, IW, sygn. 296/I-62; 296/I-64; AAN, PRM, Rkt. 49, 1, 77-8.

${ }^{12}$ CAW WBH, Rozkazy Dowództwa Okręgu Generalnego Warszawskiego, DOK I/6 (rozkazy tajne), Rozkazy oficerskie L.117 (28 July 1920) and L.120 (4 Aug. 1920); AAN, IW, sygn. 296/I-64, 31.

${ }^{13}$ AAN, PRM, sygn. 20055, 178v. See also AAN, BS, sygn. 27, 11-14; CAW WBH, Gab. MSWojsk., sygn. I.300.1.49, L. 3918; AAN, MSW, sygn. 202-974, 19. Even when the fighting had ceased, such appeals had to be repeated; CAW WBH, Gab. MSWojsk., sygn. I.300.1.50, L. 6095. On previous negotiations between the Jewish parties and the Polish government, Golczewski, Polnisch-jüdische Beziehungen, 309-11; Alfred Nossig, Polen und Juden, Wien [1921²], 51.

${ }^{14}$ Józef Piłsudski Institute of America, Akta Szefa Sztabu Generalnego Wojska Polskiego Generała Tadeusza Rozwadowskiego, sygn. 701/3/2, 45067.

15 'Zabiegi żydowskie', in Myśl Niepodległa, 509 (24 July, 1920), 631-4 and 636-8; AAN, IW, sygn. 296/I-15, 64, 106 and 138; CAW WBH, Oddz. II Szt. MSWojsk., sygn. I.300.76.246, Komunikat informacyjny no. 15 (26 Feb. 1920); Szczepański, Społeczeństwo Polski, 248 and 267. 
Jewry. ${ }^{16}$ At rallies in July 1920, the Anti-Bolshevik League bluntly demanded the removal of Jews from public offices. ${ }^{17}$ For the Gazeta Poranna newspaper, it was the Jews who had been responsible for the failures of the Polish army. The newspaper predicted more anti-Jewish excesses arising from the indignation of Polish soldiers. Therefore, the author suggested that Jews should immediately be withdrawn from the front divisions and from the officer corps. ${ }^{18}$

Soon, in some places, police activities were no longer limited to communists but extended to the entire Jewish population. ${ }^{19}$ Like the nationalist press, the official war propaganda machine lumped Jews and Bolsheviks together, perpetuating the notion of Judeo-Communism [żydokomuna]. ${ }^{20}$ Among Jews, this propaganda fuelled fears of an increase in violence while questioning the earnestness of the government's earlier efforts to curb such outrages. ${ }^{21}$ Nevertheless, the spreading of anti-Semitic ideas was not part of the official stance of the military authorities, especially of DOG. They repeatedly pointed out that indulging in anti-Semitic stereotypes in war propaganda encouraged violence against Jews and, what is more, made Jews less inclined to support Poland. 22

The pressure created by right-wing politicians and journalists was a powerful catalyst for excluding Jews from the army and the Border Protection Corps [Korpus Ochrony Pogranicza], cumulating

${ }^{16}$ Tadeusz Wawrzyński, Marek Jabłonowski, and Piotr Stawecki (eds), O niepodległa $i$ granice, ii: Raporty $i$ komunikaty naczelnych władz wojskowych o sytuacji wewnętrznej Polski 1919-1920 (Pułtusk, 2000), 35; Szczepański, Społeczeństwo Polski, 265.

${ }^{17}$ Marian Marek Drozdowski, Warszawa w obronie Rzeczypospolitej czerwiec-sierpień 1920 (Warszawa, 1993), 100. See also Józef Dowbór-Muśnicki, 'Sprawy wojskowe', in Res Publica (Jednodniówka), cited after AAN, IW, sygn. 296/I-17, 63.

${ }^{18}$ AAN, IW, sygn. 296/I-17, 41.

${ }^{19}$ In some cities, i.e. in Rzeszów, Jews were removed from vigilance committees and KOP; Szczepański, Spoteczeństwo Polski, 248.

${ }^{20}$ Examples in AAN, MSW, sygn. 202-974, 13-14; AAN, IW, sygn. 296/I-16, k. 122-123; AAN, IW, sygn. 296/I-44, 316; AAN, IW, sygn. 296/I-56, 25-32; see also., sygn. 296/I-57, 24-5.; sygn. 296/I-17, 40; AAN, IW, sygn. 296/I-56, 22. AAN, IW, sygn. 296/I-57, 8. AAN, IW, sygn. 296/I-57, 60.

${ }^{21}$ AAN, IW, sygn. 296/I-17, 40; sygn. 296/I-16, 56-7; Mieczysław B. Markowski, Spoleczeństwo województwa kieleckiego wobec wojny polsko-bolszewickiej 1919-1920 (Kielce, 1998), 171.

${ }^{22}$ CAW WBH, SRI, sygn. I.371.5/A.39, reports no. 710/20, 740/20, $810 / 20$. 
in the Jabłonna decision. Indeed, since the spring of 1920, such military practices again manifested on a larger scale. ${ }^{23}$ Under the order of MSWojsk. of 3 July 1920, it was deemed necessary to limit the percentage of Jews in the army to "a maximum of 10 per cent in the shortest possible time through the exchange of soldiers between troops stationed in Warsaw and its environs". ${ }^{24}$ Another fiat of 27 July ordered the transfer of 500 Jews to other general districts. ${ }^{25}$ It seems that activities in Rembertów, the assembly point for academic volunteers, also were part of these anti-Jewish efforts. ${ }^{26}$ About 35 per cent of the volunteers were Jews, and, according to a fiat of 29 July 1920 , two-thirds of them were evenly distributed as candidates for officers among the four officer schools in the General Districts of Warsaw, Łódź, Lublin and Cracow. However, these schools were instructed to form separate platoons. ${ }^{27}$ On 31 July 1920, 100 Jewish soldiers from the guard battalion were interned in the Warsaw garrison. About 300 Jewish nurses - one of the deputies to the Sejm had lobbied against the presence of non-Polish women ${ }^{28}$ - were nevertheless able

${ }^{23}$ Inwazja bolszewicka a Żydzi, i, passim; CAW WBH, Gab. MSWojsk., sygn. I.300.1.47, Liczb. 405 and 479. Cf. AAN, IW, sygn. 296/I-15, 13, 18; sygn. 296/I-16, 150-1; 'W sprawie usuwania żydów-żołnierzy z biur wojskowych', Nasz Kurjer (15 June 1920); 'Żer dla wrogów Polski', ibid. (18 and 21 June 1920) and the speech of Ozjasz Thon to the parliament on 29 April, 1920, Sprawozdania Stenograficzne z posiedzeń Sejmu Ustawodawczego (hereinafter: SSSU), cxlii, col. 17; 'Mowa budżetowa posła dra Thona', Nowy Dziennik (5 May 1920).

${ }^{24}$ Andrzej Serafin, Społeczeństwo Warszawy w okresie zagrożenia państwa polskiego przez najazd bolszewicki (lipiec-sierpien 1920) [MA Thesis], Uniwersytet Warszawski 1994, [n.p].

${ }^{25}$ CAW WBH, Gab. MSWojsk., I.300.1.49, L. 1993/tj. Uzup.

${ }^{26}$ Janusz Szczepański, Wojna 1920 roku na Mazowszu i Podlasiu (Warszawa-Pułtusk, 1995), 103. 205th infantry regiment, formed from volunteers, was in large majority financed by the Jewish benefactors. The regiment, which suffered tremendous losses and enjoyed high acclaim, was commanded by Major Bernard Mond; Zofia Waszkiewicz, Duszpasterstwo w sitach zbrojnych II Rzeczypospolitej (Toruń, 2002), 66; Stanisław Bernard Mond and Jan Gintel, Historja 205 Putku Piechoty Ochotniczej im. Jana Kilińskiego (Warszawa, 1932).

${ }^{27}$ CAW WBH, Oddz. I MSWojsk., sygn. I.300.7.108, L.dz. 34435. See also: a letter form a student to the Jewish Members of Parliament Club; CZA, Grünbaum Papers, A127/366, P. 2054. XXXIX.20. Jews were also being rejected by voluntary units in other places; CAW WBH, Gab. MSWojsk., sygn. I.300.1.49, L. 4179.

${ }^{28}$ CAW WBH, Gab. MSWojsk., sygn. I.300.1.49, L. 3690. 
to continue in their service..$^{29}$ On the old Warsaw fortress territory, as in other front lines, the Jewish population was displaced in anticipation of the decisive battle. ${ }^{30}$

The orders from the beginning of August, mentioned in the introduction, were the result of this self-propelling process: on 1 August 1920, Deputy Minister Kazimierz Sosnkowski informed DOG Warsaw and the Command of the Capital City of Warsaw that the percentage of Jewish soldiers in military units stationed around the capital was to be drastically reduced. ${ }^{31}$ On 6 August, in parallel with the decisions of the High Command to defend Warsaw, Sosnkowski's order was clarified; and the order, quoted at the beginning of this article, was issued to withdraw Jews from the units in the vicinity of the Polish capital. In Warsaw, Modlin, Zegrze and Jabłonna, the percentage figure of Jews among the soldiers was not to exceed five per cent. Despite the dramatic situation on the front lines, all excess numbers of Jews from the Warsaw General District were to be liquidated and brought to an assembly point yet to be established within six days. The working columns formed from them could not exceed 250 men, to whom one officer, five non-commissioned officers and ten Christian soldiers incapable of serving at the front were assigned. The order also applied to the units of institutions subordinate to MSWojsk. The retaining of Jews in "institutions on the pretext that they are necessary or politically sound" was expressly forbidden. ${ }^{32}$ The following month, DOG Warsaw, without irony, began looking for Christian soldiers who could use 'Jewish jargon', that is, Yiddish so that the military censor could employ them. ${ }^{33}$

However, the exact internal decision-making process that led to the internment remains unknown. There were rumours in the press that

${ }^{29}$ Szczepański, Wojna 1920 roku, 131. In September 1920 in Lublin two nurses were dismissed after 18 years of service because of their Jewish origins; CAW WBH, Gab. MSWojsk., sygn. I.300.1.50, L. 6033.

30 Their homes and flats were then used or plundered by the army. Szczepański, Spoteczeństwo Polski, 249. These displacements led to protests of Jewish members of parliament. Szymon Rudnicki, Żydzi w parlamencie II Rzeczypospolitej (Warszawa, 2004), 55; CAW WBH, Gab. MSWojsk., sygn. I.300.1.1331, L. 4677.

${ }^{31}$ CAW WBH, Oddz. I Szt. MSWojsk., sygn. I.300.7. 108, Rozkaz No. 156/ W.M.20. See also Golczewski, Polnisch-jüdische Beziehungen, 240-5.

32 CAW WBH, Oddz. I Szt. MSWojsk., sygn. I.300.7.108, Liczb. 13679/Mob.

${ }^{3}$ CAW WBH, Rozkazy Dowództwa Okręgu Warszawskiego, Rozkaz oficerski L. 130 (1 Sept. 1920). 
General Weygand had proposed the idea. ${ }^{34}$ Wacław Sobieski suspected that the alleged desertion of the entire battalion manned by Jews in Radzymin, as well as General Szeptycki's reports about the treacherous actions of Jewish officers, prompted the army High Command to take action. ${ }^{35}$ There is no doubt that the political and military leaders came under public pressure, as the state and army seemed to be in turmoil. Consequently, Jews were increasingly used as scapegoats. Meanwhile, deteriorating military discipline became an increasing problem for the army leadership, as too was the international press reports. As a result, Minister Leśniewski, who was still in office, banned all attacks on Jews at railway stations. ${ }^{36}$ On 30 July, Sosnkowski again made assurances at the session of the Council of National Defense [Rada Ochrony Państwa, ROP] that 'Jewish riots' would be brought under control and that further government actions were being prepared, which, in retrospect, could be understood as the coded announcement of an internment order. ${ }^{37}$

Ultimately, the military authorities confirmed rumours of the increasing 'injurious activity' of the Jews, as clearly illustrated by the pre-quoted excerpt from the 6 August order pertaining to the work of Jews in orderly rooms and offices. Since all relevant persons in the army, government and the ROP were informed of the intention to limit the number of Jews in the Warsaw garrison, the internment order itself cannot be considered an isolated event. ${ }^{38}$

\section{III}

ISOLATION AND WAR. THE INTERNMENT OF JEWISH SOLDIERS DURING THE BATTLE OF WARSAW

The old garrison in Jabłonna was chosen as the 'assembly point' for the excluded soldiers, certainly due to its convenient location and size. Regardless of this reutilisation, Jabłonna retained its full military

34 'Le général Weygand', Rzeczpospolita (27 Aug. 1920) (morning edition); 'Die Tragödie des jüdischen Volkes in Polen', in Wiener Morgenzeitung (24 Sept. 1920), 2.

${ }^{35}$ Wacław Sobieski, Dzieje Polski, iii, 2 (Warszawa, 1925), 232.

36 'Z powodu ekscesów przeciwżydowskich', Kurjer Poranny (31 July 1920); AAN, IW, sygn. 296/I-17, 99; AAN, PRM, sygn. 20055, 178v. AAN, MSW, sygn. 202-974, 19.

37 '12 posiedzenie ROP' (30 July 1920), in Dokumenty i materiaty, iii, 237-42.

38 'Czternaste posiedzenie Rady Obrony Państwa' (6 Aug. 1920), in PROP, 246. 
function. ${ }^{39}$ The transfer of Jews began on 6 August, although it was not until 13 August that the garrison's command began to separate Jews from the rest of the garrison. For example, one of the troops was sent to a nearby forest, and after a few hours, the Christian soldiers were detached, while the Jews had to return to the garrison. ${ }^{40}$ In other units, the Jews were to stand in front of the ranks during the roll-call, after which they were separated from the rest of the soldiers and treated like prisoners. Eventually, they were transported - mostly in civilian clothes and without weapons - under guard to Jabłonna. ${ }^{41}$ There were housed in several wooden barracks that were fenced off with barbed wire over time (initially, it had been easy to escape into the nearby forest). ${ }^{42}$

According to a report from July 1920, the pre-war wooden and brick garrison buildings in Jabłonna, when compared to similar facilities, were in relatively good condition after six years of war and three camp exchanges. ${ }^{43}$ However, another military report, written shortly after, described the condition of the building as 'disastrous'. ${ }^{44}$ The general conditions in Jablonna in the mid-summer of 1920 probably did not differ much from those in other garrisons, but these same conditions deteriorated significantly from July onwards. ${ }^{45}$ Jewish soldiers had to contend with an even worse situation. There were no bunks,

${ }^{39}$ Jacek Szczepański, 'Jabłonna, Legionowo, Chotomów, Nieporęt przy linii frontu Bitwy Warszawskiej', in Pola Cudna-Kowalska (ed.), Chotomów, Jabłonna od wieków razem (Chotomów-Jabłonna, 1998), 112-16; Lech Wyszczelski, Operacja Warszawska (13 sierpień - 6 wrzesień 1920 roku) (Warszawa, 2005), 295.

${ }^{40}$ CAW WBH, Gab. MSWojsk., sygn. I.300.1.1331, L. 5073, aneks D do L. 480/20; also in Inwazja bolszewicka a Żydzi, i, 134; Golczewski, Polnisch-jüdische Beziehungen, 241.

${ }^{41}$ Feliks Kuczkowski, 'Zagadka Jabłonny', Naród (1 Sept. 1920). Cf. Inwazja bolszewicka a Żydzi, i, 134; CZA, Grünbaum Papers, A127/366, P.2074. XXXIX.20; Maurice Adus, 'Na marginesie Pamiętników Witosa. W pięćdziesiątą rocznicę Jabłonny', Zeszyty Historyczne, xx (1971), 175.

42 Obóz koncentracyjny w Jabłonnie, CAW WBH, Gab. MSWojsk., sygn. I.300.1.1332.

${ }^{43}$ O Niepodległa $i$ granice, ii, 481. Ebenso AAN, PRM, Rkt. 49, iv, 230; CAW WBH, Oddz. II Szt. MSWojsk., sygn. I.300.76.247. Wooden barracks were also depicted by Adolf Reichwein in one of his letters. He spent two months in the garrison in 1917 as a German soldier. Adolf Reichwein, Ein Lebensbild aus Briefen und Dokumenten (München, 1974), 17.

${ }^{44}$ O Niepodlegta i granice, ii, 609.

${ }^{45}$ Ibid. 
mattresses, blankets or sheets. Only a few beds were available for officers and in the infirmary, where doctors had to contend with raging dysentery, scabies, and also venereal diseases. ${ }^{46}$ The seriously ill were treated in hospitals outside the camp. ${ }^{47}$ The food supply was very poor at first. Indeed, the internees received no food for at least two days. ${ }^{48}$ On 9 September, Jewish parliamentarians drew attention to the poor food supplies. ${ }^{49}$

The situation in Jablonna improved to some extent only when the families learned about the detention of the soldiers. The internees could receive 15-minute visits from their relatives at the camp gate twice a week. The guards signalled the end of the visit with rifle shots. Family contacts provided the internees with additional food provisions..$^{50}$ Moreover, after some time, institutions such as the Spójnia association, the Jewish State Defense Committee [Żydowski Komitet Obrony Państwa] and the Jewish Academic Thatch [Żydowska Strzecha Akademicka] took over three canteens at the camp. ${ }^{51}$

When the public found out about the Jabłonna camp, Jewish activists took action. Among them was Noah Pryłucki, who organised additional external support for the internees. When the guards refused to deliver aid, he unceremoniously packed donated food, sleeping bags, and mattresses on a cart and used his authority as a former member

${ }^{46}$ Biblioteka Sejmowa (hereinafter: BS), RPII/0/1574, Interpelacja posłów: Grynbauma, Thona, Farbsteina i in. (25 Nov. 1920); Kuczkowski, 'Zagadka Jabłonny', 5; Inwazja bolszewicka a Żydzi, i, 136.

${ }^{47}$ Kuczkowski, 'Zagadka Jabłonny'.

${ }^{48}$ Adus, Na marginesie, 175; Inwazja bolszewicka a Żydzi Żydzi, i, 132-5; Kuczkowski, Zagadka Jabtonny, 5. In an undated letter to the Parliamentary Club, a concerned sergeant informed about the lack of bread for 4-5 days. CZA, Grünbaum Papers, A127/366, P.2074. XXXIX.20. The year previously there had been no bread deliveries for the civilians in Jabłonna. BS, RPII/0/847, Interpelacja p. Dobrowolskiego i tow. (19 Dec. 1919).

${ }^{49}$ CAW WBH, Gab. MSWojsk., sygn. I.300.1.50, Żydowskie Stronnictwo Ludowe do MSWojsk. (9 Sept. 1920).

${ }^{50}$ Inwazja bolszewicka a Żydzi, i, 133-7; Adus, Na marginesie, 175; Kuczkowski, Zagadka Jabtonny, 5; Golczewski, Polnisch-jüdische Beziehungen, 241; CAW WBH, Gab. MSWojsk., sygn. I.300.1.50, Żydowskie Stronnictwo Ludowe do MSWojsk. (9 Sept. 1920).

${ }^{51}$ [Konrad Wrzos], 'Z wycieczki do Jabłonny', Robotnik (11 Sept. 1920), 2; Inwazja bolszewicka a Żydzi, 133 and 137; CAW WBH, Gab. MSWojsk., sygn. I.300.1.1332, Obóz koncentracyjny w Jabłonnie. 
of parliament to gain access to the camp..$^{52}$ On 7 September, the Office of Non-Catholic Denominations in MSWojsk. received a letter from the National Club of Jewish Members of Parliament [NKPŻ], with a request to grant leave for imprisoned soldiers during Jewish holidays. ${ }^{53}$ Deputy Minister Eugeniusz de Henning-Michaelis did not restrict the rabbis from entering the garrison or eating kosher food, and holding religious services within the camp. However, he did not allow for the issuing of leave passes to the prisoners. ${ }^{54}$ Though the imprisoned soldiers could not leave the camp, they moved freely in the designated areas, as they were not bound by military discipline and their participation in the exercises was compulsory only to a limited extent. ${ }^{55}$ From 25 August, they were also assigned work at railway installations. ${ }^{56}$

The reception of the Jews by the Christian inhabitants of the garrison varied greatly. The garrison commander, Lieutenant Tadeusz Słowik, had a reputation for being a decent and honest man among the internees. ${ }^{57}$ Nor is there any known misconduct on the part of the officers, ${ }^{58}$ who had generally separated themselves from the ordinary soldiers. Only the guards remained a constant threat in terms of their violence towards and harassment of the internees. These guards were

52 Kalman Weiser, Jewish People, Yiddish Nation. Noah Prylucki and the Folkists in Poland (Toronto, 2011), 195-6. In a later statement, Jewish student organisations criticised Prylucki's involvement as unauthorized as he did not cooperate with existing canteens and allegedly only distributed worthless parcels. 'Protest', in Nowiny Codzienne (28 Oct. 1922).

${ }^{53}$ CAW WBH, Biuro Wyznań Niekatolickich (hereinafter: BWN), sygn. I.300.20.131, 7 .

${ }^{54}$ CAW WBH, BWN, sygn. I.300.20.131, 11. Jewish soldiers who were not interned, despite the criticism described above, were also released in the autumn of 1920 on the occasion of Jewish holidays, which were on September 13, 14, 22, 27, and October 4. Dz. Rozk. MSWojsk. 1920 nr 34, poz. 738, 754, and also no. 10 pos. 249. Examples of further orders to release Jews from general duty during holidays. Dz. Rozk. MSWojsk. 1919, nr 41 poz. 1341 i nr 89 poz. 3258; CAW WBH, BWN, sygn. I.300.20.117, nr 1986/WWN (6 Oct. 1923).

${ }^{55}$ Kuczkowski, Zagadka Jabtonny, 5.

${ }^{56}$ CAW WBH, Gab. MSWojsk., sygn. I.300.1.1332, Obóz koncentracyjny w Jabłonnie.

57 [Wrzos], ibid.; 'Zwinięcie obozu w Jabłonnie', in Gazeta Poranna 2 Grosze (21 Sept. 1920).

${ }^{58}$ Kuczkowski, Zagadka Jabtonny. 
often war invalids who only wore police uniforms without military insignia - a circumstance perceived as a deliberate humiliation of the internees. ${ }^{59}$ The guards were mainly recruited from soldiers or field gendarmes from western Poland, commonly known as 'Poznanians'. ${ }^{60}$ After 1918, they had gained a notorious reputation as Jew-haters. ${ }^{61}$ In the camp, they also committed numerous forms of violence against the Jewish soldiers, such as tearing off military badges and insignias, and engaging in beatings. ${ }^{62}$ The commander of the guard was Roman Pupurus, who was responsible for a myriad of outrages. ${ }^{63}$ The internees, in particular, feared that the wooden barracks would be set on fire, so they organised their own guard watch. ${ }^{64}$ Nevertheless, there were numerous violent attacks. For example, 'Poznanians' on guard duty wounded a dozen or so members of a workers' battalion during their return to the garrison. ${ }^{65}$ According to Marja Baruchowa, the wife of 40-year-old war volunteer Henryk Baruch, her husband had received a series of blows from rifle butts. ${ }^{66}$ Balbina Ciężar reported that her fiancé Szlama Satin had been beaten up during work duty, and to such an extent that he could not get out of bed. ${ }^{67}$ It also happened that the guards brutally cast away, beat and harassed visiting families at the camp gate, shooting into the air. They also confiscated food parcels. ${ }^{68}$

${ }^{59}$ CAW WBH, Gab. MSWojsk., sygn. I.300.1.1332, Obóz koncentracyjny w Jabłonnie.

${ }^{60}$ Adus, Na marginesie, 175; Kuczkowski, Zagadka Jabtonny, 5; Golczewski, Polnisch-jüdische Beziehungen, 241; CZA, Grünbaum Papers, A127/367, P.2074. XXXIX.20.

${ }^{61}$ I.a., Inwazja bolszewicka a Żydzi, i, 5 and 135.

${ }^{62}$ Ibid.

63 'Na stokach cytadeli...', Nasz Przeglad (20 Aug. 1929).

${ }^{64}$ Adus, Na marginesie, 175. The wooden oil barrels described by Adus, which are said to have been placed around the barracks, are nowhere mentioned, except 'Die Tragödie des jüdischen Volkes in Polen', in Wiener Morgenzeitung (24 Sept. 1920).

${ }^{65}$ CAW WBH, Gab. MSWojsk., sygn. I.300.1.49, L. 4617. According to reports, 30 workers were beaten with truncheon blows to their heads and one was killed. See also complaints from the Narodowy Klub Posłów Żydowskich, August 11 and 13; ibid., Inwazja bolszewicka a Żydzi, i, 133-7.

${ }^{66}$ CAW WBH, Gab. MSWojsk., sygn. I.300.1.50, L. 6019.

${ }^{67}$ Ibid., List Balbiny Ciężar (10 Sept. 1920).

${ }^{68}$ Ibid., Żydowskie Stronnictwo Ludowe do MSWojsk. (9 Sept. 1920); Obóz koncentracyjny w Jabłonnie, sygn. I.300.1.1332, CAW WBH, Gab. MSWojsk.; CZA, Grünbaum Papers, A127/366, P.2074. XXXIX.20. 
Roman Pupurus mentioned above was said to have raped several Jewish women. ${ }^{69}$

Therefore, the feeling of uncertainty and danger was very justified for the internees, taking into account the almost daily anti-Jewish demonstrations of the 'Poznanians' during the retreat, especially at the railway stations. The garrison command was unable to withstand this violence. When on 23 August 1920, a military transport stopped at the railway station next to the barracks, the 'Poznanians' who were travelling with it plundered nearby Jewish stores. Jewish guards were provided with weapons by the garrison command. ${ }^{70}$ There was an exchange of shots. The intervening senior officer was beaten up. Meanwhile, the garrison command ordered the Jewish internees to turn off all the lights in the barracks so that the marauders would not notice their presence. ${ }^{71}$ This dangerous situation and the uncertain future of the internees fuelled many rumours. For example, it was generally thought that they would be sent to the front lines as 'cannon fodder'. This may have been due to the fact that in exceptional cases service at the front was accepted as an alternative to internment in Jablonna. ${ }^{72}$ One of the internees, who had volunteered for the front, created a parody of the legionary song My, Pierwsza Brygada [We, the First Brigade], in which the refrain "Jabłonna, ah Jabłonna, our vain hope" encapsulated the sense of bitterness and outrage. ${ }^{73}$

If you look at the internees as a whole, different groups can be distinguished. There were both volunteers and conscripts in the camp. The group of volunteers apparently comprised mainly academics and high school students for whom the ideas of Jewish emancipation or even acculturation were generally close. ${ }^{74}$ Probably numbering ca 300 people, they constituted a minority of the internees. Some of them had already fought in the Polish Legions. The second-largest group was ten to fifteen times larger and consisted of conscripts who had

69 'Na stokach cytadeli'. Pupurus was executed in August 1929 as the leader of a saboteur gang.

${ }^{70}$ Golczewski, Polnisch-jüdische Beziehungen, 241.

${ }^{71}$ CZA, Grünbaum Papers, A127/366.

72 Ibid.

${ }^{73}$ Czesław Miłosz, Wyprawa $w$ dwudziestolecie (Kraków, 2000), 274; Abecadto Miłosza (Kraków, 1998), 241f.; Adus, Na marginesie, 176.

${ }^{74}$ CAW WBH, Gab. MSWojsk., sygn. I.300.1.1332, Obóz koncentracyjny w Jabłonnie. 
enlisted in the army before July 1920 as part of the general military service duty of men born in 1895-1902. ${ }^{75}$ They were often members of traditional circles who made a living mainly from crafts and retail trade, and until then had shown little interest in the Polish state. Some decisions of the garrison command perpetuated the differences between social circles, which, of course, were present among the Christian population. People with higher education could count on better treatment and enjoyed various privileges. ${ }^{76}$

The names of the internees are known only in those cases where they themselves later reported their internment. One example is Józef Lejtes, who, as a film director, was one of the pioneers of Polish cinema, or Jakub Perelman, who was a Zionist-revisionist activist. ${ }^{77}$ In the case of Aleksander Rafałowski, an important representative of the artistic avant-garde, it is difficult to determine whether he was interned in Jablonna solely because of his Jewishness or because he supported the communist party. ${ }^{78}$ The internment of Józef Feldman was written about in the contemporary press, as he was the son of Wilhelm Feldman - the acclaimed writer, literary historian and the temporary head of Piłsudski's press office. ${ }^{79}$ Probably further in-depth research would reveal more names. ${ }^{80}$ The testimonies of Jewish soldiers who

${ }^{75}$ Dziennik Praw Państwa Polskiego 22 (1919), poz. 234; Dz. U. nr 48 (1920), poz. 298; Golczewski, Polnisch-jüdische Beziehungen, 241.

${ }^{76}$ Szczepański, Wojna 1920 roku, 131; CAW WBH, Gab. MSWojsk., sygn. I.300.1.1332, Obóz koncentracyjny w Jabłonnie.

77 'Listy Józefa Lejtesa do Barbary i Leszka Armatysów', Kino, 1 (1984), 17; Jacek Cybusz (ed.), 'Wspomnienia Józefa Lejtesa ze zbiorów i w opracowaniu Jacka Cybusza', iii, Tygiel Kultury, 1-3 (2005); Czesław Brzoza (ed.), Żydowska mozaika polityczna w Polsce 1917-1927. Wybór dokumentów (Kraków, 2003), 216. Canadian doctor, Ludwik Mirabel wrote that his father had been imprisoned in Jabłonna: Ludwik Mirabel, 'You See What You're Doing to Me - You Make Me Dig in the Ashes', The Newsletter of the Janusz Korczak Association of Canada, 5 (2007), 33.

78 'Aleksander Rafałowski', in Polski Stownik Biograficzny (hereinafter: PSB), xxx (1987), 443-6.

79 [Wrzos], ibid.; 'Lantisémitisme en Pologne. Les horreurs du camp de Jablonna', L'Humanité (3 Oct. 1920); Aleksander Hertz, Wyznania starego cztowieka (Warszawa, 1979), 124.

${ }^{80}$ Reports on the internment of Jewish soldiers from Ostrołęka in Eliezer Lachowicz, 'O ruchu chalucowym i robotniczym syjoniźmie w Ostrołęce' in Zalman Drezner (ed.), Księga Żydów ostrołęckich (Ostrołęka-Tel Awiw, 2002), 137. According to Manuel Rympel, there were five Jews from Cracow among the internees; Manuel 
were not at the camp but who found out about its existence are just as rare. ${ }^{81}$

It is impossible to determine the exact number of Jews interned in Jabłonna. Military sources from 1920 give numbers ranging from 3,000 to $5,300,{ }^{82}$ while later information in the literature and journalistic sources proposed three times higher numbers. ${ }^{83}$ As the capacity of the entire military complex, with similar operational activities, had indeed not reached this size, the most likely number of approx. 5,000 internees is the most probable figure. Assuming that during the fighting for Warsaw, there were only about 113-123,000 soldiers capable of arming on the Polish side, this is also a significant number. ${ }^{84}$ It is possible, however, that the fluctuation in the camp was so large that many more soldiers passed through it. However, only one press report suggests that the wooden barracks served as temporary quarters for internees: after reaching the appropriate number of soldiers, each group of 407 men was formed into a unit that was moved from a separate complex of the Jewish camp to ordinary barracks in Jabłonna. ${ }^{85}$ Although there is no doubt that the working columns under the leadership of Christian officers were transferred from Jablonna, the incomplete sources do not allow for any conclusions to be arrived at in relation

Rympel, 'Słowo o Żydach krakowskich w okresie międzywojennym (1918-1939)', in Jan Gintel (ed.), Kopiec wspomnień (Kraków, 1964²), 573.

${ }^{81}$ Czesław Miłosz recorded the account of the mathematician Alfred Tarski, Miłosz, Abecadto, 241-2. Tarski served in the army for a short period in 1918/19; Anita Burdman Feferman and Solomon Feferman, Alfred Tarski. Life and Logic (Cambridge, 2004), 26.

${ }^{82}$ CAW WBH, Gab. MSWojsk., sygn. I.300.1.49, L. 4617; sygn. I.300.1.51, Liczb. 17680. In one of the reports of the Warsaw-Prague Branch, the status of 2,577 internees and 215 guards was given; CAW WBH, sygn. I.300.1.1332, Obóz koncentracyjny w Jabłonnie; Szczepański, Wojna 1920 roku, 131.

${ }^{83}$ C. Lemercier, 'Lantisémitisme en Pologne', L'Univers Israélite (5 Oct. 1923), 84. The editors of Ringelblum's report also quote this number, listing thousands of deaths, as well as Sosnkowski's alleged order to blow up the camp in the event of a further attack by the Red Army; Emanuel Ringelblum, Ghetto Warschau. Tagebücher aus dem Chaos (Stuttgart, 1967), 42 f.; Jerzy Tomaszewski, Najnowsze dzieje Żydów w Polsce w zarysie do 1950 roku (Warszawa, 1993), 149; Reuben Ainsztein, Jüdischer Widerstand im deutschbesetzten Osteuropa während des Zweiten Weltkrieges (Oldenburg, 1995), 29-30.

${ }^{84}$ Szczepański, Wojna 1920 roku, 249 f.

${ }^{85}$ Kuczkowski, Zagadka Jabtonny. 
to the total number of internees. ${ }^{86}$ In the military sources, there is only evidence of six units of 400 or 407 men being led by a Christian officer, accompanied by a company commander with the rank of platoon commander or corporal. ${ }^{87}$

People first learned about the events unfolding in Jabłonna by way of the grapevine. ${ }^{88}$ Two weeks after the initial internments, the first articles appeared in the press. ${ }^{89}$ These reports sparked protests from both Jews and the left. On 16 August, the Jewish People's Party addressed an interpellation to Minister Sosnkowski. ${ }^{90}$ Two days later, at a session of ROP, a letter from Jewish parliamentarians was read out. According to Piłsudski's statements, even he, who had always treated Jews with respect in public, took the reports of Jewish deserters and collaborators quite seriously. As noted by Kazimierz Świtalski, the Chief of State contended that neither the front nor the rear troops should be "littered" with Jews, as most of them would end up deserting. ${ }^{91}$ The result of these contentions was the recommendation to

${ }^{86}$ For example, the Headquarters of Staff Command [Dowódca Oddziału Generalnego, DOG], Warsaw, asked on 30 Aug. 1920 for the assignment of 10 officers as commanders of working units, CAW WBH, Oddz. I Szt. MSWojsk., sygn. I.300.7. 108, L.dz. Szt. Wydz. V-a.15676/20.

${ }^{87}$ CAW WBH, Gab. MSWojsk., sygn. I.300.1.1332, Obóz koncentracyjny w Jabłonnie.

${ }^{88}$ Adus, Na marginesie, 175; Szymon Rogoziński, Moje szczęśliwe życie (Łódź, 1994), 38; Hanna Jakubowicz (Róża Rozenberg), 'Inwazja bolszewicka', in Alina Cała (ed. and pref.), Autobiografie polskiej młodzieży żydowskiej okresu międzywojennego ze zbiorów YIVO Institute for Jewish Research w Nowym Jorku (Warszawa, 2003), 141 f.

${ }^{89}$ AAN, MSZ, sygn. 9388 i 9389.

${ }^{90}$ CAW WBH, Gab. MSWojsk., sygn. I.300.1.49, Żydowskie Stronnictwo Ludowe do Rady Ministrów, 16 sierpnia. The letter was read out in the ROP; see also, sygn. I.300.1.1331, L. 5073.

91 'Szesnaste posiedzenie Rady Obrony Państwa (18.08.1920)', in Leinwand and Molenda: 'Protokoły Rady Obrony Państwa', in Z dziejów stosunków polsko-radzieckich, i (Warszawa, 1965), 262. In 1920, Piłsudski spoke about Jews on several occasions, emphasising on the one hand the stance they took in support of the Bolsheviks, and on the other, the loyalty of Polish Jews; see for example 'List Piłsudskiego do Sosnkowskiego, 29 kwietnia 1920', Rok 1920, 152; AAN, Akta Józefa i Aleksandry Piłsudskich [Józef and Aleksandra Piłsudskis Files], sygn. 11, 25; Tomasz Gąsowski, 'Józef Piłsudski wobec Żydów, kwestii żydowskiej i antysemityzmu', in Danuta Czerska (ed.), Poprzez stulecia. Ksiegga pamiatkowa ofiarowana profesorowi Antoniemu Podrazie $w$ 80. rocznice Jego urodzin (Kraków, 2000), 221-39; Szymon Rudnicki, 'Szacunek z wzajemnością. Piłsudski a Żydzi', Więź, 5-6 (2010), 72-80. 
the government to set up a commission of inquiry to investigate the allegations formulated in the interpellation. On this basis, ROP was to make further recommendations. ${ }^{92}$

On 19 August, NKPŻ sent to MSWojsk. documentation on the situation of the internees at Jabłonna. ${ }^{93}$ On 22 August, Izaak Grünbaum and Noah Prylucki met with the representative of the Prime Minister Antoni Anusz, Antoni Bujak from the Parliamentary Military Committee, Colonel Rudolf Prich representing the General Staff and Major Polakiewicz from MSWojsk. ${ }^{94}$ According to Prich, the head of the 1st Division of the General Staff, the Jabłonna situation was not about derogating from the principle of the equal treatment of all religions in the army. The number of Jews in the fighting units was limited, as units with a greater share of Jewish soldiers "had often failed in the field of battle". ${ }^{95}$ In contrast, the portion of Jews in the stationary units of the Warsaw General District had increased to as much as 40 per cent due to their alleged lack of suitability for the front. As the food and accommodation of the internees in Jabłonna had been provided in accordance with the regulations in force, Prich expressed his surprise at the reactions of the Jewish representatives. In his eyes, the actions taken by the army command had not undermined the rights of the Jews as citizens and soldiers, but had been purely guided by military considerations relating to the hostile actions of Jews at the front. Prich assured that cases of the abuse and harassment of internees would be investigated and that those responsible would be punished in accordance with the rule of law.

Pryłucki objected to this assurance, calling the steps taken by the military as "insulting to Jews and pushing them against Poland". Moreover, the brutal treatment of interned soldiers was, in his opinion,

92 Szczepański, Wojna 1920 roku, 258.

93 Inwazja bolszewicka a Żydzi, i, 131-3.

${ }^{94}$ CAW WBH, Gab. MSWojsk., sygn. I.300.1.50, 'Pismo z 7 września 1920; Komisja do zbadania obozu w Jabłonnie', Robotnik (22 Aug. 1920).

${ }^{95}$ CAW WBH, Gab. MSWojsk., sygn. I.300.1.1332. See also 'Narada Rządu z zastępcami żydowskimi’ Robotnik (22 Aug. 1920); AAN, MSZ, sygn. 9389, 2. Der Moment informed on 26 September about the next meeting between Pryłucki and Prich, after which Prich gave the assurance that the matter would be settled by MSWojsk. to the benefit of the Jews; ibid., 'Raport o prasie żydowskiej nr 24' (26 Aug. 1920). 'Prich Rudolf', in PSB, xxviii (1984-5), 462-3; Andrzej Wojtaszak, Generalicja Wojska Polskiego 1921-1926 (Szczecin, 2005), 513 f. 
completely unacceptable. He demanded equal treatment for all soldiers, the suspension of internment, the return of the internees to their units, and the creation of an investigative commission with the participation of representatives of the Jewish community ${ }^{96}$ Izaak Grünbaum stated that the task of MSWojsk. was the ending of the anti-Jewish policy. He called for a detailed examination of the accusations against the Jews and the internment order's withdrawal. He stressed that Jews should not be deprived of "the right to shed blood" by forming separate Jewish battalions. Grünbaum announced that Jewish parliamentarians would resign from their seats if the government refused to make concessions. The representatives from MSWojsk. declared that they were not empowered to make specific decisions and that they interpreted the reaction of the Jews as a result of the erroneous execution of the orders and the uncalled-for harassment of the lower ranks. They proposed a series of steps, like the establishment of a commission of inquiry, the abolition of internment, and the separation of prisoners into all general districts. ${ }^{97}$

The newspaper Robotnik informed about the talks that same day; it also published an editorial about the situation of Jews in the army and their internment in Jabłonna. ${ }^{98}$ The Yiddish press, such as Haynt, Der Tog, and others, also began reporting on these events. Der Moment published an appeal for donations for the benefit of internees. ${ }^{99}$ The army carefully noted all mentioning of Jabłonna in newspapers and prepared detailed press reports. In one of them, we can read that many Jewish newspapers assessed the actions of the army leadership as being contradictory; on the one hand, Major Bernard Mond, hailing from a Jewish family, had been awarded the Order of Virtuti Militari, and on the other hand, Jews were deemed unworthy of shedding blood for Poland. The report's author noted the clear negative impact of these events on Poland's standing abroad, especially in the USA and France. ${ }^{100}$ The following report indicated that some of the 'assimilationists' were supposed to agree with the contents of the

${ }^{96}$ CAW WBH, Gab. MSWojsk., sygn. I.300.1.1332, protokół z 22 sierpnia 1920 r.

${ }^{97}$ Ibid.

${ }^{98}$ R.K., 'Patentowanie obywateli', Robotnik (22 Aug. 1920).

${ }^{99}$ AAN, MSZ, sygn. 9389, 2.

${ }^{100}$ CAW WBH, Gab. MSWojsk., sygn. I.300.1.1332, Wydz. II DOG Warszawa do Oddz. II MSWojsk. (23 Aug. 1920). 
internment order. However, it only critically assessed how it had been carried out. ${ }^{101}$

The investigation, agreed on 22 August, was held the following day under the chairmanship of General Wroczyński, head of the Supreme Military Control. Grünbaum presented him with four complaints from prisoners. ${ }^{102}$ According to Wroczyński's report, 2,634 internees in the camp were divided into five working columns, 407 men in each. Six more columns were under preparation, as well as a separate 109-person unit for intelligence. The report shows that the internees looked healthy and content. They were being provided with food like regular soldiers, although in fact there had been supply problems in the previous days due to transport difficulties. The Jews were billeted in seven clean and 'tidy' barracks, which were to be equipped with bunks and straw bags. There was also a barracks for the sick, where a doctor worked. Due to the lack of training personnel, there had been no military exercises for the internees, but that had changed with the arrival of the officers on 22 August. Wroczyński also gave the small number of 31 non-commissioned officers as the reason why the internees had not yet been registered on name lists, and thus had not been able to receive a uniform. In addition, according to his report, about 200 guards were missing to carry out the necessary patrols. ${ }^{103}$ Meanwhile, on 24 August, NKPŻ again received a letter from the internees in Jabłonna, in which they drew attention, among others, to their unsafe situation. ${ }^{104}$

While the military cited a lack of combat readiness as the main reason for the internment of Jewish soldiers, the government made its justification the outside world by claiming that it wanted to contain the anti-Semitic sentiment that was spreading in the country because of the Jewish attitudes with respect of the enemy. ${ }^{105}$ In this interpretation,

101 Ibid., Raport polityczny (26 Aug. 1920).

102 Ibid., sygn. I.300.1.1331, L. 5073.

${ }^{103}$ An appropriate letter from Wroczyński was sent to DOG Warsaw on 25 Sept. 1920; CAW WBH, Gab. MSWojsk., sygn. I.300.1.1331, L. 5073, Aneks F do L.480/20.

${ }^{104}$ Inwazja bolszewicka a Żydzi, i, 134.

105 For General Wacław Iwaszkiewicz, the head of DOG Warsaw, it was a decision without anti-Semitic overtones and in accordance with the rational organisation of the army, because the combat strength of the unit was allegedly questionable 
the internment action was primarily intended to protect Jews. The government also tried to convey this view to the foreign press. At the said meeting in MSWojsk. on 26 August, representatives of the ministries of Internal, Foreign and Military Affairs agreed to take joint action against the expected "anti-Polish campaign in the foreign press". ${ }^{106}$ A commission was established to investigate the participation of Jews in communist organisations, the findings of which were to be used to counter the expected attacks from the press. In addition, the Ministry of Foreign Affairs representative demanded official information about the "concentration camp in Jabłonna", which the representative of MSWojsk. promised to pass on. ${ }^{107}$

Since the internment of Jewish soldiers had still not been withdrawn, at the end of August, MPs Herman Lieberman from the Polish Socialist Party [Polska Partia Socjalistyczna, PPS] and Natan Löwenstein-Opoka from the Club for Constitutional Work [Klub Pracy Konstytucyjnej] as well as the mathematician and assimilation supporter Samuel Dickstein from the 'Unification' [Zjednoczenie] jointly intervened with the Prime Minister and Minister Sosnkowski with respect of the army's anti-Jewish orders. On 30 August, they met with Sosnkowski and agreed to stop any further escalation pertaining to Polish-Jewish relations. More importantly, for the first time, both sides negotiated the possibility of releasing former legionnaires, volunteers and government officials from Jabłonna. ${ }^{108}$

even with the participation of Jews at the level of 10 per cent. CAW WBH, Oddz. I Szt. MSWojsk., sygn. I.300.7.111, L. 20216. Moreover, even after the internment order, there were calls in the army for the withdrawal of all Jews from the combat units, which, for example, is suggested by the letter from DOG Kielce.; CAW WBH, Gab. MSWojsk., sygn. I.300.1.1332 (26 Aug. 1920).

${ }^{106}$ AAN, MSZ, sygn. 9389, 21. In fact, press reports from the USA contained numerous reports of the cruel treatment of the Jewish population at the hands of the Polish military; CAW WBH, Oddz. II Szt. MSWojsk., I.300.76. 486, 12, 19, $26-28,54,65$ f., 69 f.

${ }^{107} \mathrm{Ibid}$. Information about Jabłonna reached Polish foreign missions no later than the beginning of September; AAN, Ambasada RP w Paryżu, sygn. 301, nr 84408/D.17728/I/20. All in all, according to Szymon Askenazy, Jabłonna had caused enormous damage to the reputation of Poland; $O$ niepodległa $i$ granice, v (Warszawa, 2004), 80 and 85.

108 'Kronika polityczna. W sprawie represji przeciwko Żydom', Robotnik (31 Aug. 1920); CAW WBH, Gab. MSWojsk., sygn. I.300.1.1332, pismo z 30 sierpnia 1920; bios in Czesław Brzoza (ed.), Żydowska mozaika polityczna. 
The first direct statement of members of the government about Jabłonna can be found in the minutes of the meeting of the Prime Minister on 1 September 1920, chaired by Daszyński. ${ }^{109}$ The deputy Prime Minister claimed that the Jewish nationalists, unlike the older Orthodox or assimilated Jewish population, had ensured that Jewish youth did not pass their 'citizenship exam'. The behaviour of Jews in the army and Jewish workers in the face of the threat to Warsaw had led "to the locating of Jewish soldiers in a special camp in Jabłonna". However, due to the changed military situation and new legislation on desertions, maintaining this temporary measure was no longer necessary or politically undesirable. At the same time, Daszyński continued, the abolition of internment was to be an instrument intended to limit the influence of 'Zionists and nationalists' in negotiations between the Polish government and Jewish representatives. Following the protests of assimilationists and Orthodox Jews, the demonstrative concessions and the camp's liquidation would ultimately win their support for government. ${ }^{110}$ In the face of such political acrobatics, it is difficult to assess the specific role of Daszyński in the entire Jabłonna affair. According to Adam Próchnik, he personally intervened with Piłsudski twice on behalf of the internees. ${ }^{111}$ The quoted statements shed a slightly different light on his attitude but could also have been tactical in nature. Apparently, he treated Jabłonna as a bargaining chip in the fight for the status and rights of Jewish communities. ${ }^{112}$ Moreover, being a socialist, he may have lacked the right sense of hope that the Bolshevik and also the Zionist ideology could have taken root among young Jewish men.

As I mentioned earlier, the reception of these events on the international arena had been discussed as early as 26 August. The Ministry of Foreign Affairs treated the press articles very seriously, the more

${ }^{109}$ AAN, MSZ, sygn. 9389, 12-17. See also the minutes in CAW WBH, Gab. MSWojsk., sygn. I.300.1.49, L. 4876.

110 There was also a proposal to further weaken the Zionists by convening a rabbinical assembly dominated by the Orthodox Jews, and at the same time to approach the assimilationists; see also, $14 \mathrm{f}$. The subsequent speakers, Colonel Prich and Major Polakiewicz of the 2nd Div. of Staff of MMA, repeated the already known arguments; ibid., $15 \mathrm{f}$. And so did Prich in the letter to the Council of Ministers, 4 Sept. 1920, CAW WBH, Gab. MSWojsk., sygn. I.300.1.51, Liczb. 17680.

${ }^{111}$ Adam Próchnik, Ignacy Daszyński. Życie-Praca-Walka (Warszawa, 1946), 69.

112 AAN, MSZ, sygn. 9389, $12 \mathrm{f}$. 
so as diplomats had to respond to newspaper reports. ${ }^{113}$ In the light of the experiences with the Morgenthau Commission, this action is understandable, especially since, for example, the American Jewish Committee had raised the issue of Jabłonna in a conversation with the US President. ${ }^{114}$ At the said meeting of the Council of Ministers on 1 September, it was agreed that diplomatic missions should immediately receive extensive information in order to counter allegedly untrue press reports. ${ }^{115}$ The Ministry of Foreign Affairs aimed to convince foreign public opinion that "there are no restrictions for Jews in the Polish Army" 116 and that the Jabłonna camp was "a temporary measure dictated by the need to detain a certain number of recruits until they had been assigned to their appropriate units". ${ }^{117}$ Information finally provided to the press by MSWojsk. had been agreed with NKPŻ. ${ }^{118}$

In the meantime, warfare once again moved eastward in August. Journalists and parliamentarians visited the garrison in Jabłonna, including Ozjasz Thon (29 August) and Apolinary Hartglas (8 September). ${ }^{119}$ Press releases also mobilised the liberal part of the public against Jabłonna. Due to censorship, Jan Niecisław Baudouin de Courtenay was unable to publish an article about Jabłonna in Naród with the title 'Nie mogę uwierzyć' [I Cannot Believe It]. ${ }^{120}$ Ultimately, it was Stefania

${ }^{113}$ A Memo of 14 September 1920, AAN, MSZ, sygn. 9388, 257 and 258. This collection includes articles from the English, French and German press. See also New York press reviews from August to November 1920. CAW WBH, Oddz. II MSWojsk., sygn. I.300.76.486.

114 'Le Président Wilson et la situation des Juifs en Pologne', Tribune Juive (5 Nov. 1929).

115 AAN, MSZ, sygn. 9389, 17.

116 Ibid., sygn. 9388, 254.

117 Ibid.

118 'Obóz w Jabłonnie', Kurjer Poranny (25 Sept. 1920). See also the day of 27 Sept. 1920 and AAN, IW, sygn. 296/I-18, 61. On 16 September, the Jewish deputies appealed to Sosnkowski that he would not mention in the announcement the alleged betrayal of the Jewish population that had been interned, but rather emphasise the excessive numbers of Jews in these units. This proposal was accepted; CAW WBH, Gab. MSWojsk., sygn. I.300.1.50, correspondence between NKPŻ and MSWojsk. (16 and 21 Sept. 1920).

${ }^{119}$ Inwazja bolszewicka a Żydzi, i, 135-7. See also Hartglas's comments on Jabłonna and his own involvement as a war volunteer in the defence of Warsaw; Apolinary Hartglas, Na pograniczu dwóch światów (Warszawa, 1996), $210 \mathrm{f}$.

${ }^{120}$ Jan Baudoin de Courtenay, Kwestja żydowska w Państwie Polskiem (Warszawa, 1923), 40, fn. 11. 
Sempolowska, with the support of the Union for the Defense of Human Rights, who managed to persuade 72 intellectuals to sign an open letter of protest that she had penned. The future writer, Hanna Mortkowicz-Olczakowa, helped in copying and disseminating the appeal. ${ }^{121} \mathrm{Her}$ close confidant, Stefan Żeromski, was the best-known signatory to the letter, fragments of which appeared in Robotnik. ${ }^{122}$ Among the signatories were de Courtenay, Andrzej Strug, Leon Petrażycki, Zofia Daszyńska-Golińska, Natalia Gąsiorowska, Mieczysław Niedziałkowski, Zygmunt Żuławski and many others. ${ }^{123}$ Strug would visit Jabłonna on the eve of the camp's liquidation. ${ }^{124}$

The internationally isolated Witos government no longer wanted to resist the growing public pressure at home and abroad. On 1 September, MSWojsk. ordered the closure of the 'assembly point' by 10 September. ${ }^{125}$ The internees were to be re-integrated into the army under established criteria. To this end, they were classified into four 'categories'. War volunteers and representatives of the intelligentsia were included in categories I and II. They were to return directly to their units. Craftsmen and tradesmen belonged to the third category and were assigned to special construction units. While these three groups, according to the data of MSWojsk., numbered about 1,000 people, the remaining ones numbered at ca. 4,000 soldiers, were to be located

${ }^{121}$ Hanna Mortkowicz-Olczakowa, O Stefanie Żeromskim. Ze wspomnień i dokumentów (Warszawa,1964), 292-3. The Union for the Defence of Human Rights initiated a collection of money for internees; CAW WBH, Gab. MSWojsk., sygn. I.300.1.1332, Oddz. II MSWojsk. (30 Aug. 1920).

122 'Odezwa z powodu Jabłonny', Robotnik (11 Sept. 1920); AAN, IW, sygn. 296/I-18, 24 and 27; Katrin Steffen, Jüdische Polonität. Ethnizität und Nation im Spiegel der polnischsprachigen jüdischen Presse in Polen 1918-1939 (Göttingen, 2004), 248; Adus, Na marginesie, 176; Natalia Gąsiorowska, Życie i dziatalność Stefanii Sempołowskiej (Warszawa, 1960), 49.

123 Janusz Rohoziński, Andrzej Strug, in Kazimierz Wyka et al. (eds), Literatura okresu Młodej Polski, iii (Warszawa, 1973), 192 f.; Adus, Na marginesie, 176.

124 Jerzy Rzymowski, 'Wstęp', in Andrzej Strug, Pisma wybrane. Nowele i opowiadania, i (Warszawa, 1987), 86; Rympel, Stowo o Żydach krakowskich, 573.

125 'Zwinięcie obozu w Jabłonnie', Robotnik (7 Sept. 1920); 'W sprawie obozu w Jabłonnie', Kurjer Poranny (10 Sept. 1920), cited after AAN, MSZ, sygn. 9388, 255. The PAP press release was also published in all Jewish dailies; CAW WBH, Gab. MSWojsk., sygn. I.300.1.1332, 'Raport o prasie żydowskiej nr 32' (10 Sept. 1920). The relevant military order was issued on September 4; CAW WBH, Gab. MSWojsk., sygn. I.300.1.51, Liczb. 17680. 
in the general districts of Cracow, Lviv, Lublin and Kielce, and assigned to guard services only. ${ }^{126}$

The closure of the camp lasted at least until 18 September. ${ }^{127}$ Some of the internees were transferred to the 5th company of the 2nd Regiment of the Infantry Legions in Piotrków Trybunalski, a unit unofficially considered a 'penal company' and known for its poor living conditions. ${ }^{128}$ Other soldiers were transferred in guarded wagons to other general districts, where they were assigned to working battalions. ${ }^{129}$ On 11 September, a train accident occurred during one of the transports from Jabłonna via Lublin to Lviv. As the train contained almost exclusively former internees, rumours abounded in the press of a deliberate attack. ${ }^{130}$ However, an investigation revealed that the train had derailed due to a faulty rail line. Seven passengers were killed, and 81 were injured. ${ }^{131}$

The military authorities followed the fate of the former internees from Jabłonna after their release. ${ }^{132}$ It turned out that a certain number of them had been ordered to march to other military units but remained in Warsaw without any valid documents. They were captured, transported again to Jabłonna and from there dispatched to their new units. Some of the Jewish soldiers who were sent from Jabłonna to

${ }^{126}$ AAN, MSZ, sygn. 9389, 16. In a note, probably written by Sosnkowski, it is stated that the last transport of about 1,500 Jewish prisoners to Kielce took place on September 14, which meant the final closure of the camp; CAW WBH, Gab. MSWojsk., sygn. I.300.1.50, 5747/B.P.2. According to Sosnkowski and Prich, the original idea not to intern Jews in Jabłonna, but to use them for work, originated with Daszyński; CAW WBH, Gab. MSWojsk., sygn. I.300.1.51, Liczb. 17680.

127 'Zwinięcie obozu w Jabłonnie', Gazeta Poranna 2 Grosze (21 Sept. 1920); J.F., 'W sprawie Jabłonny', Robotnik, 251 (14 Sept. 1920). Cf. CAW WBH, SRI, sygn. I.371.6/A.92, 'Raport tygodniowy z prasy żydowskiej' (6-9 Sept. 1920).

${ }^{128}$ Wniosek posła Hirszhorna i innych, Druk Sejmowy RPII/0/2100 (10 Oct. 1920).

${ }^{129}$ Inwazja bolszewicka a Żydzi, i, 135. Cf. 'Die polnische Hölle', in Jüdische Rundschau (19 Oct. 1920).

130 CAW WBH, Gab. MSWojsk., sygn. I.300.1.50, Żydowskie Stronnictwo Ludowe do MSWojsk. (17 Sept. 1929); Adus, Na marginesie, 177. French oficer Olivier d'Etchegoyen mentions the accident as well; Olivier d'Etchegoyen, Polens wahres Gesicht. Persönliche Erlebnisse aus der Gegenwart (Berlin, 1927), 68. Cf. La Tribune Juive (Dec. 1920).

${ }^{131}$ CAW WBH, Gab. MSWojsk., sygn. I.300.1.50, L. 5999.

${ }^{132}$ CAW WBH, Rozkazy DOG Warszawskiego, Rozkaz tajny nr 141, poz. 6. 
other parts of the country escaped the transports, returned to their mother units and, to the displeasure of the military authorities, were accepted back into the ranks. ${ }^{133}$

\section{IV}

\section{DISILLUSIONMENT AND UNDERSTANDING. JEWISH AND NON-JEWISH OPINIONS}

The internment of Jews in Jabłonna is an event of great symbolic importance. The Battle of Warsaw was a turning point in the war that seriously threatened the existence of the Polish state. The defence of the capital itself was understood as the collective achievement of the entire nation, and was something like the actual birth date of the Second Polish Republic. The demonstrative exclusion of Jews from the community of citizens and defenders of the homeland was not only a discriminatory measure but also a symbol of the greatest significance. This fact also immediately became apparent among Jewish families whose sons had not been affected by the internment. ${ }^{134}$ Józef Lichten learned about Jabłonna at the age of 14 , and it came as a profound blow to him, "the first disappointment of youth, realising that Jews are treated as 'others' or perhaps even 'strangers', when they previously had considered themselves to be an integral part of Poland and its society". ${ }^{135}$ Moshe Sneh, a Zionist activist in Poland; and in the 1930s still known as Mojżesz Kleinbaum, called Jabłonna in retrospect "a symbol of the Polish-Jewish tragedy". According to him, the Jews faced a dilemma: if they refused to volunteer for the war, they were considered deserters; however, if they did volunteer, they were treated as suspects. ${ }^{136}$

As already mentioned, the press described the events in Jabłonna in more detail only two weeks after the first internment, and the newspapers arrived at very different conclusions. As Gazeta Poranna

133 Ibid., Rozkaz Tajny nr 148, poz. 7.

134 Jakubowicz, Inwazja bolszewicka, 141; Rogoziński, Moje szczęśliwe życie, 38.

135 Józef Lichten, 'Żydzi w Polsce dwudziestolecia', Zeszyty Historyczne, 57 (1981), 201. Similarly Lejtes in Cybusz (ed.), 'Wspomnienia Józefa Lejtesa' iii.

${ }^{136}$ Moshe Sneh, 'Yesterday without a Morrow', in David Flinker (ed.), The Jewish Press That Was. Accounts, Evaluations and Memories of Jewish Papers in Pre-Holocaust Europe (Jerusalem, 1980), 45. 
2 Grosze noted, Jabłonna was by no means the kind of torment as described in the left-wing press. The camp may have been liquidated, but there was still a long way to go in terms of the "solution of the Jewish question within the Polish Army". ${ }^{137}$ Elsewhere in the same newspaper, it was written that Poland had to take one lesson from the war: that the Jewish population should not be relied upon to build the state as many of them had treacherous and hostile intentions. The examples of positive cooperation with the army, mentioned many times by Piłsudski, had not been proven. If the authorities had not pursued the Jews, it would have meant that the treason would have been legalised. ${ }^{138}$

The accounts of some other newspapers were more nuanced, and their correspondents primarily tried to present reliable facts, bearing in mind that the internees had been wronged. In Naród, Feliks Kuczkowski expressed a great deal of empathy for the internees. ${ }^{139}$ The newspaper Robotnik dealt primarily with the incalculable influence of internment on the nascent democracy. On 29 August 1920, the newspaper informed about problems with the treatment of minorities by the state, Jews in particular. It criticised not only the harassment of non-Poles but also the protests on the Polish side against international condemnation. The example of Jewish soldiers demonstrated the absurdity of this strategy: on the one hand, they had been detained as collaborators, and on the other hand, they had been denied a fair trial. In Robotnik's opinion, this approach had served to deprive the Jewish soldiers of their dignity and isolated them from the rest of the citizenry. ${ }^{140}$ Therefore, the author of the article called for an increase in civil liberties and a responsible stance on the part of all citizens. Six days later, on 4 September, the same newspaper informed about new transports to Jabłonna, which took place despite the decision of the Polish government to close the camp. The author attacked the government's inaction and feared protests from abroad against the treatment of Polish Jews. Jabłonna, he wrote, was a form of collective punishment that was contrary to the modern understanding of law

137 'Zwinięcie obozu w Jabłonnie', Gazeta Poranna 2 Grosze (21 Sept. 1920).

138 'Konieczne konsekwencje', Gazeta Poranna 2 Grosze (31 Aug. 1920).

Cf. Piłsudski, Pisma zbiorowe, v, 165-7.

${ }^{139}$ Kuczkowski, Zagadka Jabtonny.

${ }^{140}$ R.K., 'Patentowanie obywateli', Robotnik (29 Aug. 1920). 
and the principle of equality in terms of the binding constitutional provisions. The only reason for the internment was the Jewishness of the people in question, who were paying the price for Jewish deserters and agents. Poland could not expect any political benefits from the internment of old legionnaires who had already fought alongside Piłsudski and Sosnkowski for six years and won military honours. Moreover, Robotnik demanded that the decision-making process be clarified, as only ROP would have the right to order such a measure. Ultimately, it concluded that the Jabłonna order had been nothing more than an incomprehensible "anti-Semitic reaction". ${ }^{141}$

In a follow-up article, Robotnik went even further in its criticisms: there should be no compromise on the equal status of all Polish citizens. This would not only be an unprecedented violation of tradition but could also be a prelude to pogroms. And more importantly,

the liquidation of the Jabłonna camp does not eliminate the issue of the separation of Jewish soldiers from the rest of the army. ... The stigma of treason cast over the entire Jewish population of 2 million has not been expiated: in order to obtain full rights as a citizen of the Polish Republic, every Jewish man must prove his loyalty by joining the army as a volunteer. ... The existence of the Jabłonna camp was an aberration that could not continue a moment longer. So a compromise was reached: the volunteers returned to the status of equal citizens, the rest were no longer prisoners but moved to a special category of suspects. ${ }^{142}$

NKPŻ held a very similar opinion on the continuation of the unequal treatment of Jews in the army, according to which the division of soldiers into 'blue blood' and 'the mob' was unworthy of democracy. Thus, Poland followed in the footsteps of the tsarist empire, where only the Jewish elite exercised its civil rights. An ordinary Jew, on the other hand, remained a 'helot of the Polish Army'. ${ }^{143}$ The news of the internment stripped the government of all credibility among the Jewish population, especially as doubts had been voiced about its sincerity in previous years. An important role was played by the fact

141 'Jabłonna', Robotnik (4 Sept. 1920). Konrad Wrzos's account is in a similar vein; [Wrzos], Wycieczki. Cf. AAN, IW, sygn. 296/I-18, 412; Adus, Na marginesie, 173.

142 J.F., 'W sprawie Jabłonny', Robotnik (14 Sept. 1920).

143 CAW WBH, Gab. MSWojsk., sygn. I.300.1.50, Narodowy Klub Posłów Żydowskich do ROP (27 Sept. 1920). 
that, along with the internment policy, the authorities tried to reach an agreement with Jewish representatives on the status of Jews in society and the state. ${ }^{144}$ When Alfred Nossig, the mediator appointed to these negotiations weeks earlier, found out about Jabłonna, he condemned it as "the greatest disgrace that the Polish army had brought upon itself and the Jews". ${ }^{145}$ The events of August 1920 were also reflected at a local level, e.g. in Tarnów, where Jews made up half of the inhabitants. While negotiating local relations between Jews and Poles, one of the Jewish representatives remarked that "it is difficult for Jews to say: be a patriot when one is simultaneously removed from work; when one is locked up in Jabłonna". ${ }^{146}$

Ultimately, the dispute over Jabłonna had its culmination at a parliamentary level. On 24 September 1920, Jewish Sejm deputies proposed a well-documented emergency motion. ${ }^{147}$ In this motion, the parliamentarians wrote of the anti-Jewish violence on the part of the military that had lasted six months and confronted the government on its promises. They described the committed engagement of many Jews on the Polish side, the rise of anti-Semitic sentiments, the numerous repressions, and finally, the Jabłonna camp. According to the materials contained in the motion, the accusations against Jews were shown to have been unfounded. However, the government's actions, which included the censorship of Jewish newspapers; and delaying the answers to parliamentary questions, had stoked anti-Jewish sentiment. ${ }^{148}$ On 14 October 1920, during a general debate in the Sejm Izaak Grünbaum once again referred to the treatment of Jews during the war and criticised the internment of soldiers in Jabłonna. ${ }^{149}$

${ }^{144}$ Szymon Rudnicki, 'Rozmowy Żydów z rządem w okresie obrad Sejmu Ustawodawczego' in Jolanta Żyndul (ed.), Rozdziat wspólnej historii. Studia z dziejów Żydów w Polsce ofiarowane profesorowi Jerzemu Tomaszewskiemu $w$ siedemdziesiata rocznice urodzin (Warszawa, 2001), 199-210.

${ }^{145}$ Nossig, Polen und Juden, 56.

${ }^{146}$ CAW WBH, SRI, sygn. I.371.5/A.39, $264 \mathrm{f}$.

${ }^{147}$ Emergency motion of MPs Grünbaum, Farbstein, Hartglas and others, Druk Sejmowy nr 2066; cf. Wniosek posła Hirszhorna i innych, Druk Sejmowy nr 2126; 'Drażliwa kwestya' Dzień (27 Aug. 1920).

148 BS, RPII/0/1574, Interpelacja postów: Grynbauma, Thona, Farbsteina i in., 25 listopada 1920; AAN, PRM, sygn. 12403/21, 4-20.

${ }^{149}$ Izaak Grünbaum, Żótta łata. Walka o zniesienie ograniczeń prawnych (Warszawa, 1922), ii, 3-23; SSSU 172, col. 41-57. 
Sosnkowski did not understand this and complained that the Jewish representatives had been busy organising comfortable living conditions for interned Jews, while Poles fought for their state. ${ }^{150}$

All these debates in parliament and in the press anchored Jablonna in the Jewish collective consciousness of the time as an anti-Semitic act that had discriminated against loyal citizens and patriots of Jewish origin. In the eyes of many, the internment became the ultimate proof of the futility of the emotional and civic involvement of Jews in Polish affairs. Shortly before his death, Apolinary Hartglas recalled in Israel that "this lack of trust oppressed everyone, and curbed the rights of Jewish society as citizens of the state to enjoy full equality". ${ }^{151}$ The Lublin-born journalist and philosopher, Émile Meyerson (Emil Mejerson), who travelled to Poland in May 1921 as head of the Paris branch of the Jewish Colonization Association, also spoke of the "vile and stupid insult that Jabłonna represented". ${ }^{152}$

Considering the wide response, it is surprising that Jabłonna received relatively little attention in the subsequent years. Numerous publications on the contribution of Jewish soldiers to the Polish struggle for independence also do not mention Jabłonna. ${ }^{153}$ A rare example of mentioning Jabłonna in a Jewish publication is a 1922 press review in the magazine Rozwaga, which, according to the assimilation program, opposed the "glorification of the Jabłonna case". ${ }^{154}$ The fact that the collective wound suffered in 1920 was still fresh was demonstrated by the reactions to Sosnkowski's return to MSWojsk. in September 1921. Lodzer Tageblatt described him as "a friend of the Jews", "who does not miss any opportunity to display his radical-anti-Semitic tendencies". ${ }^{155}$ On the occasion of Sosnkowski's resignation from the post of Minister

${ }^{150}$ CAW WBH, Gab. MSWojsk., sygn. I.300.1.51, L. 8566.

${ }^{151}$ Hartglas, Na pograniczu, 210.

152 Rapport de M. Meyerson sur son voyage en Pologne, Mai 1921, CZA, Meyerson Émile, A408/91, 10.

${ }^{153}$ See Norbert Getter, Jakub Schall, and Zygmunt Schipper, Żydzi bojownicy o niepodlegtość Polski. Ilustrowana monografia $w$ opracowaniu zbiorowym (Lwów, 1938; reprint Warszawa, 2002); Janusz Konrad Urbach, Udziat Żydów $w$ walce o niepodlegtość Polski (Warszawa, 1938).

154 'Z trybuny i prasy', Rozwaga, vii, 1 (1922), 30.

${ }^{155}$ CAW WBH, Oddz. II SG, sygn. I.303.4.1693, 27. Leon Reich also criticised the appointment of Sosnkowski to the position of Minister in the second government of Grabski; SSSU, Protokół z 90 posiedzenia Sejmu (21 Dec. 1923), col. 10. 
for War in February 1924, the Yiddish press once again recalled his dubious role in the summer of $1920 .{ }^{156}$ In June 1931, Nasz Przeglad recalled Jabłonna in connection with the statements of the Vilnius voivode about the situation of Jews in Poland. ${ }^{157}$

One of the few non-Jewish criticisms came from Andrzej Strug, who had visited the camp several times. In his novel Pokolenie Marka Świdy [The Generation of Marek Świda] (1925), Nusym is a Jewish friend of the protagonist, who, in the face of the Russian advance, "despite everything that is there and how things are with us", remains optimistic. The fact that he himself ended up "in Jabłonna in a Jewish camp" was worthy of nothing more than a laconic remark: "Didn't your beloved deputy minister make a right mess of this". 158

It is hardly surprising that the opponents of the Jews chose not to forget about Jabłonna. ${ }^{159}$ Several anti-Semitic publications assessed the measures taken by the military in August 1920 as having been necessary and suggested them as guidelines for a future military personnel policy. ${ }^{160}$ Indeed, even after 1920, there were still voices in the army that were convinced of the need for internment. ${ }^{161}$ In the academic community, historian Wacław Sobieski had similar views, considering Sosnkowski's decision to have been a logical consequence of the treacherous behaviour of many Jewish soldiers. ${ }^{162}$ The three-volume Historia Polski [History of Poland] by Sobieski, featuring his

${ }^{156}$ CAW WBH, Oddz. II SG, sygn. I.303.4.2689, 'Polityczny raport miesięczny o prasie żydowskiej (1 Feb. - 1 March 1924). See also 'Deklaracja Koła Żydowskiego odczytana przez posła Reicha', Nasz Przeglad (22 Dec. 1922).

157 'Żądanie bohaterstwa', Nasz Przegląd (5 May 1931).

158 Andrzej Strug, Pokolenie Marka Świdy (Kraków, 1985), 115.

159 'Nowy obrońca Żydów', Gtos Narodowy (29 July 1938).

160 Walenty Zieliński, 'Rola żydów w wojsku i w stosunku do wojska', in Pamiętnik I. Konferencji Żydoznawczej odbytej w grudniu 1921 roku w Warszawie (Warszawa, 1923); Jan Zelewski, Kwestja żydowska w Polsce (Poznań, [1938]), 17; Tadeusz Mścisławski, Wojsko Polskie a Żydzi (Warszawa, 1923), 27-8; 'Szabesgoje', in Kurjer Bydgoski (28 Oct. 1937); ‘Wspólnicy Jakóba Cyryńskiego’, Myśl Niepodległa (16 Aug. 1924).

${ }^{161}$ Roman Umiastowski, Terytorjum Polski pod względem wojskowym, i (Warszawa, 1921), 188; Georg Zychowski, 'Die jüdisch-bolschewistische Gefahr', in Hans Krebs and Eugen von Engelhardt (eds), Die Weltfront. Stimmen zur Judenfrage, i, 1 (Berlin-Leipzig, 1935), 105-17.

162 Sobieski, Dzieje Polski, 232. Sam Weygand did not claim that he had participated in Poland's victory; Maxime Weygand, Bitwa o Warszawę. Odczyt wygloszony w Brukseli (Warszawa, 1930). 
interpretation of the Jabłonna case, received positive reviews from, among others, Kurier Poznański. 163

All in all, it can be said that the 1918-1921 period in the collective memory of Polish Jews was not dominated by the processes of exclusion in the army, but rather the experience of violence. For this reason, the memory of Jabłonna, where there were no casualties, did not take on such importance as a place of memory as the pogroms and acts of violence did in Lviv, Lida, Vilnius or Pińsk. The memory of Jabłonna seemed to fade with the German occupation and the communist period. In the discussion on the admission of Jews to Anders' army, 'Jabłonna' apparently was no longer a point of reference, even though issues similar to those of 1920 were negotiated. The Second World War and the Holocaust pushed Jabłonna into the background. ${ }^{164}$ In official historiography after 1945, Jabłonna had been a place of suffering for the Polish working classes, as one of the many overcrowded prisons and internment camps in revolutionary times that workers and peasants remembered "to this day". 165

However, Jabłonna returned to the scientific and cultural discourse as a symbol, as a historiographic code that excludes the tendencies of Polish nationalism. For the first time in 1974 in exile, Witold Babiński raised this topic in connection with Sosnkowski's role in the Polish-Bolshevik war in an archival report for the Parisian Zeszyty Historyczne. As Sosnkowski's former adjutant, he assessed the actions of his superior as a reaction to the behaviour of Jews towards the enemy and a measure to stop violence against Jews. ${ }^{166}$ In 1977, in Zeszyty Historyczne, Maurice Adus and Adam Ciołkosz assessed the topic also from the perspective of a generation of contemporary witnesses: Adus saw it as a consequence of omnipresent anti-Semitism

${ }^{163}$ I. Chrzanowski, 'To nie antysemityzm, lecz całkiem coś innego', Kurier Poznański (11 Jan. 1936).

164 The exceptions are Simon Segal, 'Eastern Europe', American Jewish Year Book, xlvi (1944/1945), 244; Kalman Stein, 'Jews in the Polish Army', Jewish Frontier, xi (1944), 17. For Stein, Jabłonna was "a tiny place situated in the Carpathian Mountains".

${ }^{165}$ Henryk Raort [Rappaport], 'Walki rewolucyjne w Polsce w latach 1918-1923', Myśl Wspótczesna, 2 (1951), 254. Zygmunt Młynarski also claimed that leading communists had been interned in Jabłonna; Zygmunt Młynarski, Szkice $z$ dziejów rewolucyjnej prasy w Polsce 1866-1938 (Warszawa, 1963), 170; Rympel, Stowo o Żydach krakowskich, 573.

${ }^{166}$ Witold Babiński, 'Z materiałów archiwalnych', Zeszyty Historyczne, xxx (1974), 30. The article was written in Dec. 1970. 
in Polish society, and the socialist Ciołkosz endeavoured to relativise the events. ${ }^{167}$ From that time onwards, Jabłonna's reception outside Poland began to take on a life of its own, which - without presenting new facts - led to Jabłonna being almost stereotypically described as an example of indigenous Polish hatred towards Jews. In some publications, it even appeared almost as a prelude to the Holocaust. ${ }^{168}$

With the opening of the historical discourse in the years of Solidarity, Jabłonna's case was discussed for the first time. A lecture by Jan Józef Lipski delivered in March 1981 as part of a series of lectures organised at the University of Warsaw to commemorate the student unrest of 1968, represented a significant contribution. Like other events, Lipski's lecture, in which he incorporated Jabłonna's theme into his account of anti-Jewish lines of tradition in Poland, was available to all students and, given the keen interest in the subject of March 1968 , it was undoubtedly well received. ${ }^{169}$ Soon after, the essay 'Dwie ojczyzny - dwa patriotyzmy' [Two Homelands - Two Patriotisms] was published, which today is considered a turning point in Polish historical discourse, in which Lipski problematised Poland's treatment of Jews and other minorities, also based on Jabłonna. ${ }^{170}$

Ciołkosz's text was re-published in 1983 - again outside of Poland. ${ }^{171}$ In the same year, a new debate developed around Jabłonna. Kultura in

${ }^{167}$ Adus, Na marginesie; Adam Ciołkosz, 'Dzielnica Żydowska obozu w Jabłonnie', Zeszyty Literackie, xx (1971). Ciołkosz was also a member of the parliamentary Military Commission; AAN, BS, sygn. 22, 31.

168 David Engel, In the Shadow of Auschwitz. The Polish Government-in-Exile and the Jews 1939-1942 (Chapel Hill, N.C., 1987), 27; Celia S. Heller, On the Edge of Destruction: Jews of Poland between the Two World Wars (New York, 1977), 51 f.; Paweł Korzec, 'Antisemitism in Poland', in Joshua A. Fishman (ed.), Studies on Polish Jewry 1919-1939. The Interplay of Social, Economic and Political Factors in the Struggle of a Minority for its Existence (New York, 1974), 51 f.; id., Juifs en Pologne, 113; Michael C. Steinlauf, Bondage to the Dead. Poland and the Memory of the Holocaust (Syracuse, 1997), 20, Simon Wiesenthal, Recht, nicht Rache: Erinnerungen (Berlin, 1992), 268; Ainsztein, Jüdischer Widerstand, 29-30. The only non-Polish publication that places Jabłonna in a broader historical context is Golczewski, Polnisch-jüdische Beziehungen, 240-5. 169 Jan Józef Lipski, 'Kwestia żydowska', Marzec 68. Referaty z sesji na Uniwersytecie Warszawskim w 1981 roku (Warszawa, 2006), 151-74.

${ }^{170}$ Jan Józef Lipski, 'Dwie ojczyzny - dwa patriotyzmy. Uwagi o megalomanii narodowej i ksenofobii Polaków', in Powiedzieć sobie wszystko, Eseje o sasiedztwie polsko-niemieckim (Gliwice-Warszawa, 1996), 38.

${ }^{171}$ Adam Ciołkosz, Walka o prawdę (London, 1983), 235-50. 
Paris published an appeal for a Polish-Jewish rapprochement, signed by Michał Borwicz, Józef Lichten, Simon Wiesenthal, Jan Karski, Jerzy Lerski and Jan Nowak, wherein they recalled the internment of Jewish soldiers in $1920 .{ }^{172}$ In response, Witold Babiński pointed to a large number of desertions and undisciplined Jewish soldiers as having been the cause of the actions taken by the Polish leadership in the Polish-Bolshevik war. ${ }^{173}$ Michał Borwicz, a former Home Army soldier, spoke again, repeating the facts about Jabłonna mentioned by Ciołkosz and Adus. ${ }^{174}$ These debates paved the way for a broader discourse on this subject, the more so as it was mentioned more frequently in the memoirs and family histories of Jews from Poland. ${ }^{175}$

Over time, Jabłonna changed from a blank spot in historiography to a known episode of the Polish-Soviet war. Although no systematic studies on these events have been published to date, historians such as Janusz Szczepański have managed to foreground Jabłonna in the 1920 narrative and place it within the fractured story of Polish-Jewish relations. ${ }^{176}$ In many recent works, Jabłonna has been thematised and contextualised, although some authors still prefer to steer clear of the topic. ${ }^{177}$ Meanwhile, several popularising publications have recently covered Jabłonna. ${ }^{178}$ Voices that deny, trivialise or justify the camp's existence are not likely to be included in the scholarly discourse but have not been wholly silenced in journalism. ${ }^{179}$

transl. Barry Keane

172 Michał Borwicz, Józef Lichten, Szymon Wiesenthal, Jan Karski, Jerzy Lerski, and Jan Nowak, 'Sprawa stosunków polsko-żydowskich', Kultura, 432 (1983), 93.

${ }^{173}$ Witold Babiński, 'Deklaracja w sprawach polsko-żydowskich', Kultura, 435 (1983), 155-6.

${ }^{174}$ Michał Borwicz, 'Uwagi nt. obozu w Jabłonnie w związku z art. W. Babińskiego (Kultura, nr 12/1983)', Zeszyty Historyczne, lxvii (1984), 226-9.

175 Mark Verstandig, I Rest My Case (Melbourne, 1995), 80. Maria Nurowska described the suicide of a Jewish officer who had been interned in Jabłonna in the novel Postscriptum (Warszawa, 1989), 125.

176 Szczepański, Wojna 1920 roku, 353-4 and 368; id., Spoteczeństwo Polski; id., Społeczność żydowska, 237 f., 246. Cf. Drozdowski, Warszawa w obronie, 222.

${ }^{177}$ In numerous works on the Polish-Bolshevik war, Janusz Odziemkowski and Lech Wyszczelski do not mention the internment of Jews.

178 Andrzej Krajewski, '25 dni hańby', Focus Historia Ekstra, 2 (2013), 72-7.

179 Jacek Arkadiusz Goclon, W obronie Europy. Wojna $z$ bolszewicka Rosja $w 1920$ roku (Toruń, 2006), 132-8; Rafał Maszkowski, 'Inny świat - obraz Żydów w Radiu Maryja', Kwartalnik Historii Żydów, 4 (2006), 669-87. 


\section{SELECTED BIBLIOGRAPHY}

Borwicz Michał, 'Uwagi nt. obozu w Jabłonnie w związku z art. W. Babińskiego (Kultura, nr 12/1983)', Zeszyty Historyczne, lxvii (1984), 26-9.

Borwicz Michał, Józef Lichten, Szymon Wiesenthal, Jan Karski, Jerzy Lerski, and Jan Nowak, 'Sprawa stosunków polsko-żydowskich', Kultura, 432 (1983).

Golczewski Frank, Polnisch-jüdische Beziehungen 1881-1922. Eine Studie zur Geschichte des Antisemitismus in Osteuropa (Wiesbaden, 1981).

Grünbaum Izaak, Żótta tata. Walka o zniesienie ograniczeń prawnych (Warszawa, 1922). Henschel Christhardt, Jeder Bürger Soldat. Juden und das polnische Militär (1918-1939) (Göttingen, 2020).

Inwazja bolszewicka a Żydzi. Zbiór dokumentów (Warszawa, 1921).

Kowalski Tadeusz Antoni, Mniejszości narodowe w Siłach Zbrojnych Drugiej Rzeczypospolitej Polskiej, 1918-1939 (Toruń, 1998).

Szczepański Janusz, Wojna 1920 roku na Mazowszu i Podlasiu (Warszawa-Pułtusk, 1995).

Christhardt Henschel - history of 19th- and 20th-century Poland, Jewish history of East Central Europe; military history; post-doc researcher in the German Historical Institute in Warsaw; e-mail: henschel@dhi.waw.pl 